\title{
IDENTIFIKASI PENYEBAB PENYAKIT LODOH PADA SEMAI KALIANDRA
}

Identification of pathogen causes of damping off diseases on kaliandra seedlings

\author{
Nur Hidayati \\ Balai Besar Penelitian dan Pengembangan Bioteknologi dan Pemuliaan Tanaman Hutan \\ Jl. Palagan Tentara Pelajar Km 15 Purwobinangun, Pakem, Sleman, Yogyakarta \\ email: inunghidayati@yahoo.com
}

Tanggal diterima: 3 Juli 2018, Tanggal direvisi: 2 Agustus 2018, Disetujui terbit: 11 Desember 2018

\begin{abstract}
Seedling quality is one of factors determining the success of forest management. Pathogen attack that causes disease in the nursery is one reason hindering the target of seedling provision. Therefore, disease outbreak in the nursery need to be properly studied to set precautionary or control measures. The aim of this study is to isolate and identify causes of damping off which cause the death of kaliandra (Calliandra callothyrsus) seedlings. A number of kaliandra seedlings from 30 gram seed of kaliandra, died due to damping off disease. Dead seedling samples were isolated then observed macroscopically and microscopically (examined under the microscope). Koch Postulate test was conducted to identify the disease causing the death of kaliandra seedlings. Identification results indicate that the causes of damping-off disease are Fusarium sp. and Rizoctonia solani.
\end{abstract}

Keywords: pathogen, nursery, Rizoctonia solani, Fusarium sp.

\begin{abstract}
ABSTRAK
Salah satu faktor yang menentukan berhasilnya pengelolaan hutan adalah tersedianya bibit tanaman kehutanan yang berkualitas. Serangan patogen yang menyebabkan penyakit di persemaian merupakan salah satu penyebab tidak terpenuhinya target penyediaan bibit tanaman kehutanan yang dibutuhkan. Oleh karena itu, berkembangnya penyakit di persemaian perlu dipelajari agar dapat dilakukan tindakan pencegahan atau pengendalian secara tepat. Penelitian ini bertujuan untuk isolasi dan identifikasi penyebab penyakit lodoh yang menyebabkan kematian pada kecambah benih kaliandra (Calliandra calothyrsus). Sebanyak 30 gram benih kaliandra disemaikan dan kecambah benih kaliandra yang menunjukkan kematian karena penyakit lodoh di persemaian diisolasi kemudian isolat diamati secara makroskopis dan mikroskopis, dilakukan uji Postulat Koch untuk mengidentifikasi penyebab penyakit yang menyebabkan kematian pada semai kaliandra. Hasil identifikasi menunjukkan bahwa penyebab penyakit lodoh adalah jamur Fusarium sp. dan Rizoctonia solani.
\end{abstract}

Kata kunci: penyebab penyakit, persemaian, Rizoctonia solani, Fusarium sp.

\section{PENDAHULUAN}

Kaliandra (Calliandra calothyrsus) adalah salah satu spesies kaliandra yang sangat populer di Indonesia, terutama di masyarakat yang berada pada areal kawasan hutan di pulau Jawa, sebagai tanaman serbaguna untuk konservasi lahan, reklamasi lahan marginal, hijauan pakan ternak, lebah, penyedia pupuk hijau dan bubur kayu (pulp) untuk membuat kertas (Tangendjaya, Ibrahim, \& Palmer, 1992). Kaliandra merupakan pohon kecil bercabang yang tumbuh mencapai tinggi maksimum $12 \mathrm{~m}$ dan diameter batang maksimum $20 \mathrm{~cm}$ (Stewart et al., 2014). Tanaman ini disebut sebagai tanaman pionir karena kemampuannya untuk hidup pada berbagai jenis tanah dan juga sering dikenal sebagai tanaman perintis karena memiliki viabilitas hidup yang tinggi (Hendrati \& Hidayati, 2014).

Tanaman dapat terserang penyakit karena adanya inokulum oleh berbagai macam patogen, dapat menginfeksi di dalam tanah, air, dan udara, bahkan menginfeksi sel inang (Pawar \& Nasreen 2016). Salah satu jenis penyakit yang sering di temukan pada benih dan pembibitan yaitu penyakit lodoh (damping off) yang merupakan suatu penyakit yang disebabkan oleh jamur. Jamur merupakan mikrorganisme yang mempunyai dinding sel, umumnya tidak bergerak, tidak mempunyai klorofil serta tidak mampu melakukan proses fotosintesis atau menghasilkan bahan organik dari karbondioksida dan air 
(organisme heterotrof) (Robinson, 2001). Preemergency damping off terjadi ketika benih terinfeksi dan mati sebelum muncul di permukaan tanah. Sedangkan post emergency damping off, serangan penyakit muncul ketika benih sudah berkecambah di permukaan tanah yang menyebabkan bibit rebah dan mengalami kematian (Omokhua, God-Egein, \& Okereke, 2009).

Pengadaan bibit tanaman kehutanan yang berkualitas dengan jumlah yang cukup dan waktu yang tepat, merupakan salah satu faktor yang menentukan keberhasilan pengelolaan hutan. Salah satu kendala yang menyebabkan tidak terpenuhinya target penyediaan bibit adalah adanya serangan patogen yang menyebabkan penyakit pada semai. Oleh karena itu, berkembangnya penyakit di persemaian perlu dipelajari agar dapat dilakukan tindakan pencegahan atau pengendalian secara tepat. Penelitian ini bertujuan untuk mengisolasi dan mengidentifikasi penyebab penyakit lodoh (damping off) pada semai kaliandra.

\section{BAHAN DAN METODE}

\section{A. Waktu dan tempat}

Penelitian dilaksanakan di persemaian dan laboratorium hama dan penyakit tanaman Balai Besar Penelitian dan Pengembangan Bioteknologi dan Pemuliaan Tanaman Hutan (BBPPBPTH) Yogyakarta. Kegiatan ini dilaksanakan pada Januari sampai dengan Maret 2017.

\section{B. Bahan dan alat penelitian}

Penelitian ini menggunakan materi benih kaliandra (C. callothyrsus) sebanyak $30 \mathrm{~g}$. Bahan yang digunakan untuk menumbuhkan jamur patogen di laboratorium adalah media Potato Dekstrose Agar (Oxoid), sedangkan untuk mengamati morfologi jamur menggunakan mikroskop (merek Zeiss Axioplan 2 dengan perbesaran $40 \times$ ).

\section{Metode Pengamatan}

\section{Persiapan benih kaliandra}

Benih kaliandra direndam di dalam air panas $<100^{\circ} \mathrm{C}$ selama 24 jam sebelum disemaikan, dibagi ke dalam 5 bak tabur, masingmasing bak tabur sebanyak $6 \mathrm{~g}$ benih. Media tanam yang digunakan berupa pasir yang sudah diberi fungisida cair. Benih yang berkecambah dan yang mati dihitung. Benih yang mati di ambil menggunakan pinset steril dan dimasukan pada cawan petri untuk diisolasi.

\section{Isolasi penyebab penyakit lodoh pada semai kaliandra}

Media PDA sebanyak $39 \mathrm{~g}$, dimasukkan ke dalam beaker glass, ditambah $1000 \mathrm{ml}$ aquades steril. Setelah dilarutkan, media tersebut disterilisasi dengan autoklaf selama 20 menit pada suhu $121^{\circ} \mathrm{C}$ dan tekanan $1 \mathrm{~atm}$. Cawan petri dan media yang telah disterilisasi, dipersiapkan di LAF (Laminar Air Flow). Sebanyak $10 \mathrm{ml}$ media ditempatkan di dalam masing-masing cawan petri.

Pada penelitian ini, isolasi dilakukan dengan cara semai yang diambil dari bak tabur dan menunjukkan kematian dibersihkan menggunakan aquades steril selama 3 menit sehingga benih tersebut terpisah dari pasir. Enam wadah dipersiapkan dengan pembagian wadah 1 (alkohol 96\%), wadah 2 (aquades steril), wadah 3 (bleaching), wadah 4 (aquades steril), wadah 5 (aquades steril) dan terakhir kertas saring/tissue steril. Benih tersebut direndam dan digoyangkan agar merata di masing-masing wadah (1-5) yang telah disiapkan selama 3 menit secara bergantian, selanjutnya benih ditanam di dalam media PDA di dalam cawan petri. Subkultur dilakukan untuk memindahkan miselium jamur yang tumbuh dari kecambah benih yang ditanam pada media PDA sehingga diperoleh biakan murni. Hasil isolasi yang tumbuh pada setiap media dalam cawan petri di subkultur sebanyak 6 ulangan. Dalam setiap cawan terdapat 4 materi tanam yang disubkultur, dipilih bagian yang tidak terkontaminasi, dipotong ukuran $1 \times 1 \mathrm{~mm}$, kemudian letakkan pada media PDA baru. Pengamatan dilakukan setiap hari dengan melihat kontaminasi dan koloni miselium jamur yang tumbuh. 


\section{Uji Patogenitas isolat jamur hasil isolasi}

Patogenitas isolat hasil isolasi yang diperoleh diuji dengan uji Postulat Koch. Uji ini dilakukan dengan menginokulasi kecambah benih kaliandra yang ditumbuhkan pada media tabur pasir, dengan inokulum dari biakan murni jamur hasil isolasi yang diinkubasikan dalam cawan petri selama 8 hari. Biakan murni jamur dipanen dengan menambahkan aquades steril sebanyak 10 $\mathrm{ml}$ kemudian dilakukan pengenceran sampai $10^{-2}$. Inokulasi dilakukan pada kecambah kaliandra berumur 7 hari setelah benih ditabur, dengan cara menyemprotkan suspensi spora jamur hasil isolasi yang diperoleh secara merata ke seluruh permukaan kecambah.

\section{Pengamatan morfologi isolat dan identifikasi jamur penyebab penyakit lodoh}

Identifikasi dilakukan secara mikroskopis yaitu pengamatan pada spora, hifa, septa jamur penyebab penyakit hasil isolasi dan pengamatan secara makroskopis melalui morfologi dan pertumbuhan isolat jamur pada media. Pengamatan gejala dan tanda penyakit lodoh juga dilakukan pada kecambah benih kaliandra yang terserang penyakit lodoh. Hasil isolasi biakan murni penyebab penyakit subkultur yang telah tumbuh dibuat preparat untuk identifikasi. Bagian yang telah ditumbuhi jamur diambil $1 \times 1 \mathrm{~mm}$, diletakan pada gelas obyek, lactopenol diteteskan menggunakan mikro pipet sebanyak $5 \mu \mathrm{l}$, ditutup dengan cover glass lalu ditekan dan di beri label. Diamati di bawah mikroskop. Hasil pengamatan mikroskopis kemudian dideskripsikan dengan menggunakan acuan pustaka (Barnet \& Hunter, 2006).

\section{Analisa data}

Data dianalisa dengan menghitung persen perkecambahan benih kaliandra serta pengamatan secara mikroskopis dan makroskopis isolat penyebab penyakit lodoh pada kecambah benih/semai kaliandra.

\section{HASIL DAN PEMBAHASAN}

\section{A. Luas serangan penyakit lodoh pada kecambah benih kaliandra}

Luas serangan penyakit pada kecambah benih kaliandra sebesar 59,03\%, merupakan persentase jumlah kecambah benih kaliandra yang terserang penyakit lodoh dibandingkan dengan jumlah semua kecambah benih kaliandra yang diamati. Benih kaliandra yang digunakan dalam penelitian ini dieksplorasi pada tahun 2011 dan selama ini disimpan di DCS pada suhu $0^{\circ} \mathrm{C}$ (komunikasi pribadi, Hendrati, 2018). Kualitas benih akan mengalami penurunan secara linear dengan waktu (Siahaan, 2017). Howell (2007) mengatakan dalam penelitiannya bahwa benih dengan kualitas yang baik sering terhindar dari serangan pre emergence damping off yang disebabkan oleh jamur Pythium spp. dan Rhizopus oryzae, dan benih ini juga tahan terhadap serangan post emergence damping off yang disebabkan oleh jamur Rhizoctonia solani. Sedangkan benih berkualitas buruk sangat rentan terhadap kedua penyakit lodoh dan membutuhkan perawatan benih untuk bertahan hidup. Hasil pengamatan menunjukkan adanya kematian kecambah dengan gejala pembusukan pada pangkal batang sehingga menyebabkan kecambah bibit rebah dan mati (Gambar 1). Gejala seperti ini dikenal dengan penyakit lodoh. Penyakit lodoh adalah pembusukan pada benih/kecambah benih di bak tabur atau semai pasca penyapihan di polibag yang merupakan gangguan yang disebabkan oleh munculnya jamur (Sturrock et al., 2015). Penyakit lodoh dapat disebabkan oleh berbagai macam penghuni tanah (soil inhibitant) bersifat parasit fakultatif yang bertahan hidup baik sebagai spora yang berada dalam kondisi dorman atau sebagai saprofit yang aktif dalam pembusukan bahan organik di dalam tanah (Hill \& Waller, 1988). Insiden penyakit lodoh yang terjadi pada semai kaliandra dalam penelitian ini termasuk dalam post emergence damping off yaitu mulai nampak adanya serangan penyakit pada kecambah kaliandra umur 10 hari. Serangan terjadi pada benih yang telah berkecambah dan telah muncul di atas tanah, fase ini terjadi pada 
kecambah yang berumur antara 1-4 minggu (Semangun, 2006).

\section{B. Isolasi dan identifikasi penyebab penyakit lodoh}

Sebagian penyakit dapat didiagnosis melalui pengamatan dengan mata langsung maupun dengan bantuan mikroskop. Sebelum melakukan pengamatan terhadap patogen, terlebih dahulu kita harus menumbuhkan atau membiakan penyebab penyakit tersebut. Mikroorganisme dapat berkembang biak dengan alami atau dengan bantuan manusia (Agrios, 2005). Mikroorganisme dapat ditumbuhkan dan dikembangkan pada suatu substrat yang disebut media. Media yang digunakan untuk menumbuhkan dan mengembangbiakan mikroorganisme harus sesuai susunannya dengan kebutuhan jenis-jenis mikroorganisme yang bersangkutan (Soni, 2010). Pengamatan hasil isolasi dilakukan setiap hari dengan melihat koloni miselium jamur yang tumbuh. Setelah miselium jamur tumbuh dilakukan peremajaan atau subkultur yang bertujuan tetap memberikan nutrisi yang cukup pada miselium jamur, untuk mendapatkan biakan murni, serta mempertahankan galur murni tanpa perubahan fisiologi, morfologi dan genetika.

Setelah dilakukan isolasi dan diperoleh biakan murni jamur yang diduga sebagai penyebab penyakit lodoh, kemudian dilakukan uji patogenitas dengan uji Postulat Koch pada kecambah benih kaliandra sehat. Suspensi spora hasil isolasi dengan pengenceran 10-2 disemprotkan secara merata pada kecambah kaliandra. Setelah itu dilakukan isolasi kembali kecambah benih kaliandra yang mati setelah diinokulasi. Hasil isolasi dan reisolasi jamur diidentifikasi dengan cara melihat struktur morfologi secara makroskopis dan mikroskopis isolat jamur pada media. Isolasi dan identifikasi dilakukan untuk mengetahui jenis patogen yang menyerang tanaman yang diamati (Agrios, 2005). Hasil identifikasi dengan melihat morfologi isolat jamur (Gambar 2 dan Gambar 3) diperoleh ada 2 jenis jamur yang menyebabkan penyakit lodoh, yaitu jamur Fusarium sp. dan Rhizoctonia solani. Johnson et al. (2014) menyebutkan bahwa penyakit lodoh disebabkan oleh jamur yang berada di dalam tanah (soil borne fungi). Jamur tersebut diantaranya adalah Pytium sp., Fusarium sp., Rhizoctonia sp., Phytoptora sp., dan jamur lainya (Abbasi, Conn, \& Lazarovits, 2004).

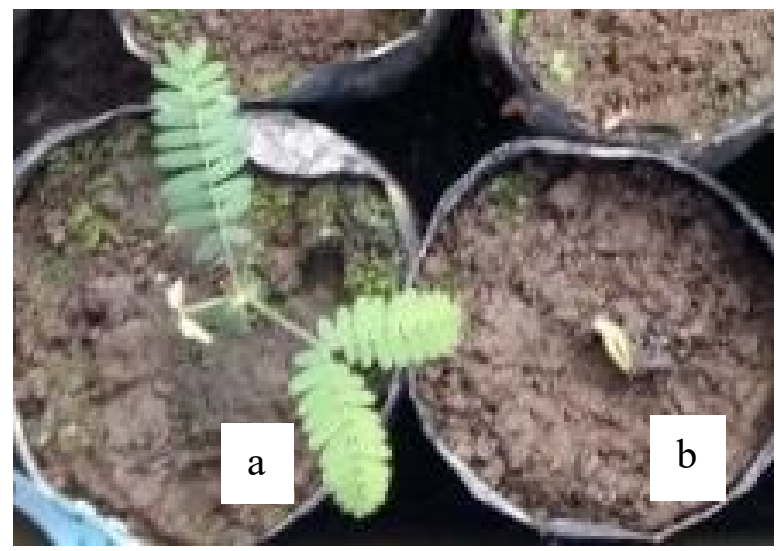

Gambar 1. Semai kaliandra (a) yang sehat dan (b) yang terserang penyakit lodoh

Hasil pengamatan makroskopis isolat yang teridentifikasi sebagai jamur $R$. solani, menunjukkan terdapat sklerotia melingkar pada isolat berwarna coklat, miselium hialin berwarna putih pada awal pertumbuhannya selanjutnya akan berubah menjadi berwarna gelap dengan pola penyebaran yang konsentris, struktur permukaan halus dan rata, tepi koloni rata, dan warna bagian bawah koloni berwarna putih kecoklatan, sedangkan pada pengamatan mikroskopis percabangan hifa tampak tegak lurus, memiliki sekat, badan buah aseksual tidak ditemukan konidia, serta tidak ditemukan adanya hubungan jepit/ clamp connection (Barnet \& Hunter, 2006). Hal ini sesuai dengan pernyataan Agrios (2005) bahwa jamur Rizochtonia solani dapat diidentifikasi dari karakter hifa yang khas, yaitu sudut percabangan yang tegak lurus yang membedakan dengan jamur lainnya. Jamur ini bertahan di tanah dengan memproduksi sklerotia berwarna cokelat kemerahan hingga hitam sebagai struktur bertahan. Sklerotia merupakan sekumpulan hifa yang memadat, berwarna gelap dan mampu bertahan dalam kondisi lingkungan yang tidak menguntungkan (Agrios, 2005). Jamur $R$. solani dapat berkembang baik pada kelembaban yang tinggi $(>80 \%)$ dan suhu 15 - 
$35^{\circ} \mathrm{C}$. Jamur ini mulai menginfeksi tanaman sejak biji baru ditanam dengan mengeluarkan stimulan kimia yang dilepaskan oleh sel-sel yang terinfeksi ke tanaman selanjutnya dan menyebabkan gejala khas pada batang, pelepah, daun, dan bulir. Jamur dapat bertahan hidup pada musim dingin sebagai sklerotia pada sisa-sisa tanaman yang terinfeksi dan di dalam tanah (Soenartiningsih, Akil, \& Andayani, 2015).
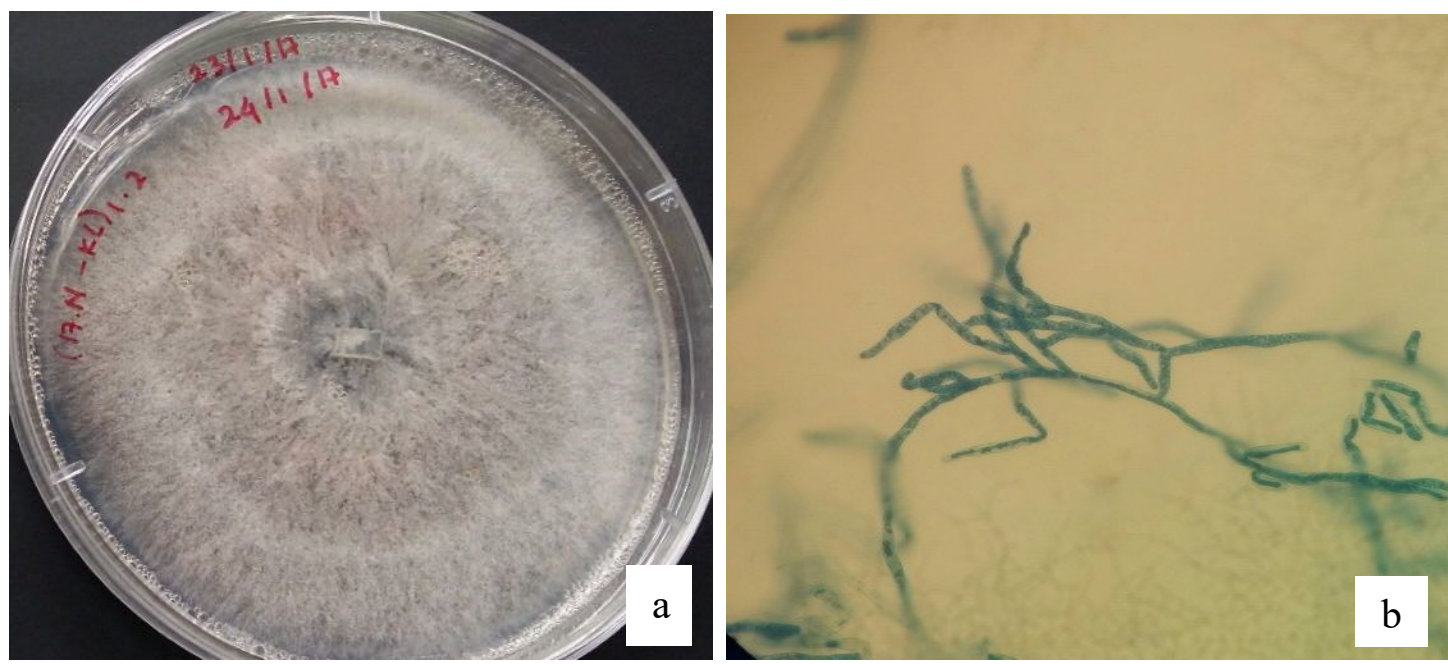

Gambar 2. (a) Isolat jamur Rhizoctonia solani (b) Jamur Rhizoctonia solani

Klasifikasi jamur R. solani (Alexopoulos, Mims, \& Meredith, 1996) adalah sebagai berikut:

$\begin{array}{ll}\text { Domain } & \text { : Eukaryota } \\ \text { Kingdom } & \text { : Fungi } \\ \text { Phylum } & \text { : Deuteromycota } \\ \text { Kelas } & \text { : Deuteromycetes } \\ \text { Ordo } & \text { : Agonomycetales } \\ \text { Genus } & \text { : Rhizoctonia } \\ \text { Species } & \text { : Rhizoctonia solani }\end{array}$

Jamur ini tumbuh dari spora dengan struktur yang menyerupai benang, ada yang mempunyai dinding pemisah dan ada yang tidak. Benang secara individu disebut hifa, dan massa benang yang luas disebut miselium. Miselium adalah struktur yang berpengaruh dalam absorbsi nutrisi secara terus-menerus sehingga jamur dapat tumbuh dan pada akhirnya menghasilkan hifa yang khusus menghasilkan spora reproduktif (Saragih, 2009). Miselium terutama terdapat di dalam sel khususnya di dalam pembuluh, juga membentuk miselium yang terdapat di antara sel-sel, yaitu di dalam kulit dan di jaringan parenkim di dekat terjadinya infeksi.
Pada pengamatan mikroskopis isolat yang lain, menunjukan adanya makrokonidia (berbentuk bulan sabit) dan mikrokonidia, hifa bersepta yang di dalamnya juga terdapat nukleus. Sedangkan morfologi isolat jamur tersebut menunjukan koloni berwarna putih pada awal pertumbuhan dan akan berubah warna menjadi merah muda, ungu atau kuning di miselium pada media (Barnet \& Hunter, 2006), hifa bersepta dengan pola penyebaran yang konsentris, struktur permukaan halus dan convex, tepi koloni entire atau rata. Agrios (2005) menyatakan bahwa jamur fusarium mempunyai 3 alat reproduksi, yaitu mikrokonidia, makrokonidia, dan klamidospora. Makrokonidia berbentuk melengkung, panjang dengan ujung yang mengecil dan mempunyai satu atau tiga buah sekat. Mikrokonidia merupakan konidia bersel 1 atau 2, dan paling banyak dihasilkan disetiap lingkungan bahkan pada saat patogen berada dalam pembuluh inangnya. Makrokonidia mempunyai bentuk yang khas, melengkung seperti bulan sabit, terdiri dari 3-5 septa. Klamidospora memiliki dinding tebal, dihasilkan pada ujung miselium yang sudah tua atau di dalam makrokonidia, terdiri dari 1-2 septa 
dan merupakan fase atau spora bertahan pada lingkungan yang kurang baik. Menurut Agrios (2005), miselium yang dihasilkan oleh jamur patogen penyebab penyakit lodoh ini mulanya berwarna putih keruh, kemudian menjadi kuning pucat, merah muda pucat sampai keunguan. Jamur Fusarium merupakan patogen yang memiliki struktur bertahan berupa klamidospora sehingga dapat bertahan selama 40 tahun di dalam tanah sebagai saprofit (Sastrahidayat, 2011).
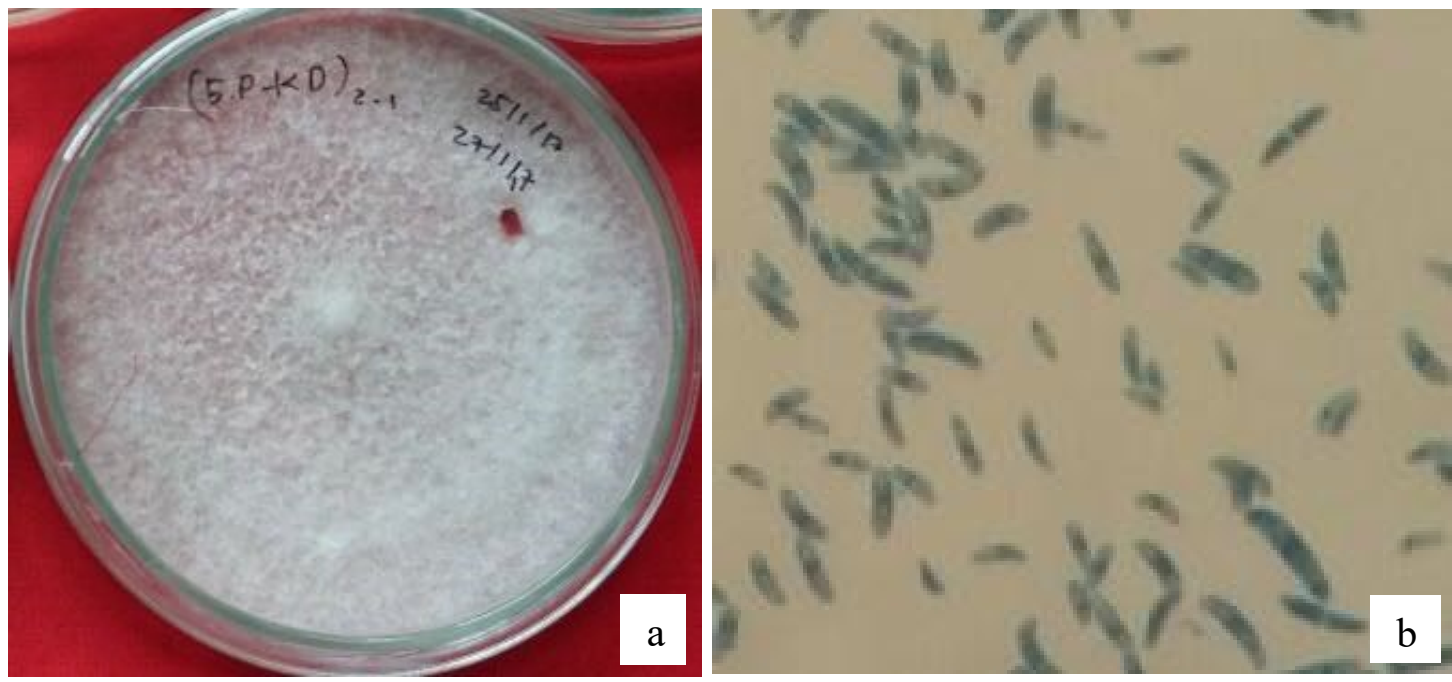

Gambar 3. (a) isolat jamur Fusarium sp. (b) spora jamur Fusarium sp.

Menurut Alexopoulos, Mims, dan Meredith (1996) bahwa jamur fusarium ini termasuk dalam Ordo Moniliales dan famili Tuberculariaceae. Klasifikasinya sebagai berikut:

$\begin{array}{ll}\text { Kingdom } & \text { : Mycetaceae } \\ \text { Divisi } & \text { : Amastigomycota } \\ \text { Kelas } & \text { : Deuteromycetes } \\ \text { Famili } & \text { : Moniales } \\ \text { Genus } & \text { : Fusarium } \\ \text { Spesies } & : \text { Fusarium } \mathrm{sp.}\end{array}$

Jamur Fusarium sp. dapat tumbuh sebagai saprofit pada sisa-sisa tanaman dan dapat disebarkan melalui angin dan hujan. Jamur ini dapat menyebar melalui bagian tubuh jamur yang melekat pada batang bagian luar atau dalam batang dan melalui tanah yang terkontaminasi oleh jamur tersebut (Arsensi \& Mardji, 2018). Patogen penyebab layu fusarium ini cepat berkembang pada tanah yang terlalu basah atau becek, kelembaban udara yang tinggi, dan $\mathrm{pH}$ tanah yang rendah (Tjahjadi, 1989). Secara ekonomi Fusarium sp. adalah patogen penting dalam pertanian hortikultura di dunia (Singleton et al., 1993). Jamur Fusarium bersifat soil inhibitant sehingga dapat bertahan sangat lama sampai beberapa tahun di dalam tanah tanpa adanya inang dari jamur Fusarium tersebut (Semangun, 2006). Fusarium hidup sebagai parasit dan saprofit pada berbagai tanaman terutama pada bagian pembuluhnya, sehingga tanaman menjadi mati karena toksin (Sastrahidayat, 1986). Pada tanaman Eucalyptus pellita, jamur Fusarium spp. menyerang benih, baik sewaktu masih di pohon induk, di penyimpanan maupun pada benih yang sedang berkecambah (Brown et al., 2000).

\section{KESIMPULAN}

Hasil isolasi dan identifikasi secara makroskopis dan mikroskopis menunjukkan bahwa penyebab penyakit lodoh adalah jamur Rhizoctonia solani dan Fusarium sp. Hal ini dibuktikan dengan uji patogenesitas isolat jamur yang diperoleh dengan uji Postulat Koch. Serangan penyakit lodoh pada semai kaliandra termasuk dalam post emergency damping off dimana serangan terjadi pada benih yang telah 
berkecambah dan tumbuh di atas tanah. Gejala yang ditunjukkan akibat penyakit ini adalah adanya pembusukan pada pangkal batang atau hypokotil akar sehingga semai menjadi layu dan mati.

\section{UCAPAN TERIMA KASIH}

Penelitian dilakukan dengan dana DIPA Balai Besar Penelitian dan Pengembangan Bioteknologi dan Pemuliaan Tanaman Hutan (BBPPBPTH). Terima kasih penulis sampaikan kepada Dr. Ir Rina Laksmi Hendrati, MP. yang telah membimbing penulis dalam penulisan naskah, kepada Tim penelitian Kayu Energi BВPРВРTH, Fatahalani mahasiswi PKL dari Universitas Jendral Soedirman dan semua pihak yang telah membantu dalam pelaksanaan penelitian dan penyediaan referensi dalam penulisan naskah.

\section{DAFTAR PUSTAKA}

Agrios, G. N. (2005). Plant Pathology (5th ed). San Diego, USA: Elseviere Academic Press. https://doi.org/https://doi.org/10.1016/B978-008-047378-9.50004-X

Alexopoulos, C. J., Mims, C. W., \& Meredith, M. B. (1996). Introductory Mycology (4th ed.). New York: John Wiley \& Sons. Inc.

Arsensi, I., \& Mardji, D. (2018). Identifikasi Patogen Penyebab Busuk Batang, 2(1), 21-25.

Barnet, H. L., \& Hunter, B. B. (1998). No Title Ilustrated Genera of Imperfect Fungi (4th ed.). Minnesota, Australia: The American Phytopathological Society St. Paul, Minnesota.

Brown, B. N., Keane, P. J., Kile, G. A., \& Podger, F. D. (2000). Diseases and fungi of the reproductive structures of eucalypts. In Diseases and pathogens of eucalypts (pp. 103118).

Hendrati, R. L., \& Hidayati, N. (2014). Budi daya Kaliandra untuk Bahan Baku Sumber Energi. Direktorat Jenderal Bina Usaha Kehutanan.

Hill, D. J., \& Waller, J. M. (1988). Pest and Disease of Tropical Crops. Netherlands.

Howell, C. R. (2007). Effect of Seed Quality and Combination Fungicide- Trichoderma spp. Seed Treatments on Pre- and Postemergence Damping-Off in Cotton. Phytopathology, 97(1), 66-71. https://doi.org/10.1094/PHYTO-970066
Omokhua, G. E., God-Egein, M. I., \& Okereke, V. C. (2009). Damping-off Disease of two Pulp and Paper Forest Species (Pinus caribaea Morelet and Pinus oocarpa Schiede ) in the Nursery, 3(4), 275-282.

Pawar, D. S., \& Nasreen, S. (2016). Isolation and Identification of Some Pathogenic Fungi from Different Infected Vegetables, 2921-2924. https://doi.org/10.15680/IJIRSET.2016.050303 2

Robinson, R. (2001). Biology Macmillan Science Library. USA: Macmillan.

Saragih, S. D. (2009). Jenis-Jenis Fungi Pada Beberapa Tingkat Kematangan Gambut.

Sastrahidayat, I. R. (1986). Ilmu Penyakit Tumbuhan. Surabaya: Penerbit Usaha Nasional.

Sastrahidayat, I. R. (2011). Epidemiologi Teoritis Penyakit Tumbuhan. Malang: UB Press Universitas Brawijaya.

Semangun, H. (2006). Pengantar Ilmu Penyakit Tumbuhan. Yogyakarta: Gadjah Mada University Press.

Siahaan, F. A. (2017). Pengaruh kondisi dan periode simpan terhadap perkecambahan benih kesambi (Schleichera oleosa (Lour .) Merr). Jurnal Perbenihan Tanaman Hutan, 5(1), 1-11. Retrieved from http://lipi.go.id/publikasi/pengaruh-kondisidan-periode-simpan-terhadap-perkecambahanbenih-kesambi-schleichera-oleosa-lourmerr/17922

Singleton, J. W., Hanauer, S. B., Gitnick, G. L., Peppercorn, M. A., Robinson, M. G., Wruble, L. D., \& Krawitt, E. L. (1993). Mesalamine Capsules for The Treatment of Active Crohn's Disease: Results of a 16-Week Trial. Gastroenterology, 104(5), 1293-1301.

Soenartiningsih, Akil, M., \& Andayani, N. N. (2015). Cendawan Tular Tanah (Rhizoctonia solani) Penyebab Penyakit Busuk Pelepah pada Tanaman Jagung dan Sorgum dengan Komponen Pengendaliannya. Iptek Tanaman Pangan, 10(2), 85-92. Retrieved from http://ejurnal.litbang.pertanian.go.id/index.php/ ippan/article/view/3507/2969

Soni, A. (2010). Isolasi Dan Pemurnian Mikroba, Teknik Pemeliharaan Kultur Murni Dan Perhitungan Angka Lempeng Total (Total Plate $=p c$ ). Universitas Brawijaya.

Stewart, J., Mulawarman, Roshetko, J. M., \& Powell, M. H. (2014). Produksi dan Pemanfaatan Kaliandra (Calliandra calothyrsus): Pedoman Lapang. Igarss 2014. https://doi.org/10.1007/s13398-014-0173-7.2 
Sturrock, C. J., Woodhall, J., Brown, M., Walker, C. Mooney, S. J., \& Ray, R. V. (2015). Effects of damping-off caused by Rhizoctonia solani anastomosis group 2-1 on roots of wheat and oil seed rape quantified using X-ray Computed Tomography and real-time PCR. Frontiers in Plant Science, https://doi.org/10.3389/fpls.2015.00461
Tangendjaya, B. E. W., Ibrahim, T. M., \& Palmer, B. (1992). Kaliandra (Calliandra calothyrsus) dan Manfaatnya. Balai penelitian Ternak dan The Australian Centre For Institute Agriculture Research.

Tjahjadi, N. (1989). Hama dan penyakit Tanaman. Yogyakarta: Kanisius. 